\title{
Agresi Provokasi dan Non-Provokasi pada Monyet Ekor Panjang (Macaca fascicularis, Raffles 1821) Terhadap Pengunjung di Kawasan Gunung Meru
}

\section{Provocated and Non-Provocated Aggressions of Long-tailed Macaques (Macaca fascicularis, Raffles 1821) to Human Visitors at Gunung Meru}

\author{
Ainul Mardiah ${ }^{1)^{*}}$, Rizaldi ${ }^{1)}$ dan Wilson Novarino ${ }^{2)}$ \\ ${ }^{1)}$ Laboratorium Ekologi Hewan Jurusan Biologi FMIPA Universitas Andalas \\ ${ }^{2)}$ Museum Zoologi Jurusan Biologi FMIPA Universitas Andalas \\ *Koresponden: ainulmardiah.48@gmail.com
}

\begin{abstract}
The study on aggressive behavior of long-tailed macaques has been conducted from May to July 2016 at Gunung Meru, Padang, West Sumatra. This study aimed to compare between provocated and non-provocated aggressive behaviors of the macaques toward human visitors at Gunung Meru feeding site. This study used all-occurrence sampling method to record aggressive interactions from the macaques along the visitors behavior. One or more visitors were followed for ten minutes at the monkey feeding ground for a total 78.5 hours. The aggressive behaviors of long-tailed macaques either provocated or non-provocated were considerably high intensity level, including body contact and biting. Feeding contexts (i.e. food exposure, feeding, and contact feeding) become the main situation resulting provocative aggressions. This study suggest that monkeys and human visitors have a potential close contact and could be pathogen transmission.
\end{abstract}

Keywords: aggressive, long tailed macaque, provocated and non-provocated

\section{Pendahuluan}

Monyet ekor panjang (Macaca fascicularis, Raffles 1821) dapat hidup berdampingan dan berinteraksi dengan manusia. Interaksi interspesies ini sering terjadi di tempat yang disakralkan atau disebut dengan istilah monkey temples atau monkey forest. Monkey forest tersebar di Asia Selatan dan Asia Tenggara, dan beberapa diantaranya telah berubah menjadi destinasi wisata, yang berkontribusi dalam pendapatan ekonomi masyarakat lokal (Schilaci, et al., 2010; Fuentes dan Gamerl, 2005).

Sumatera Barat memiliki beberapa tempat wisata (monkey forest) yang tersebar di beberapa lokasi yaitu di Panorama Kota Bukittinggi, Lembah Anai, Gunung Padang, Gunung Pangilun dan Gunung Meru. Gunung Meru merupakan daerah wisata alam yang terletak di Teluk Nibung, dekat dengan pantai. Terdapat tiga kelompok monyet ekor panjang di Gunung Meru (Koyama, 1984; Ilham 2013; Ilham, 2016).
Monyet dapat berhabituasi dan bahkan masuk ke pemukiman masyarakat. Tidak adanya pembatas fisik atau pagar antara monyet dengan pengunjung menyebabkan pengunjung dapat berinteraksi langsung dengan monyet ekor panjang.

Pengunjung sering memberikan makanan dan berinteraksi dalam jarak dekat dengan monyet. Interaksi yang sangat dekat ini berpotensi menyebabkan terjadinya peningkatan agresifitas monyet ekor panjang terhadap pengunjung $(\mathrm{Fa}, 1992)$.

Monyet ekor panjang bisa menularkan SFV (simian foamy virus) dan Herpes B yang berasal dari mukosa monyet tersebut melalui gigitannya ketika menyerang pengunjung. Pengunjung juga berpotensi tertular penyakit flu A dan B, serta campak. Tingkah laku pengunjung seperti kontak mata, kontak fisik, menginjak ekor, mengusik, atau membiarkan monyet memanjat tubuh mereka, berpotensi 
menimbulkan kemarahan monyet, karena monyet dapat terprovokasi (Fuentes dan Gamerl, 2005).

Minimnya pengetahuan masyarakat tentang cara yang tepat berinteraksi dengan monyet dari jarak dekat dapat menimbulkan kerugian dikedua belah pihak. Oleh karena itu, dilakukan penelitian untuk mengetahui agresifitas monyet ekor panjang yang diprovokasi dan non-provokasi di Gunung Meru. Hasil penelitian ini dapat menjadi informasi tentang bagaimana mencegah timbulnya agresif monyet terhadap pengunjung.

\section{Metode Penelitian}

Penelitian ini dilaksanakan pada bulan Mei sampai bulan Juli 2016 di Gunung Meru, Padang, Sumatera Barat. Terdapat 3 kelompok monyet ekor panjang di kawasan Gunung Meru yaitu kelompok A (35 individu), kelompok B (29 individu) dan kelompok C (68 individu) (Ilham, 2016). Kelompok yang sama merupakan subjek penelitian ini.

Pengamatan tingkah laku agresif monyet ekor panjang baik yang terprovokasi maupun non-provokasi oleh pengunjung dikumpulkan melalui metoda all-occurences sampling (Altmann, 1974; Martin dan Bateson, 1993; Beisner, et al., 2014) yaitu mencatat semua kejadian provokasi atau non-provokasi dan agresif yang terjadi antara satu atau sekelompok pengunjung dengan monyet ekor panjang.

Pengkoleksian data tingkah laku pengunjung dan monyet ekor panjang mengacu pada Fuentes dan Gamerl (2005) dengan cara mengikuti pengunjung yang terdiri dari 1 atau lebih selama 10 menit dengan total pengamatan 78,5 jam. Selama pengamatan, dicatat interaksi provokasi atau non-provokasi yang dilakukan pengunjung terhadap monyet dan kategori tingkah laku agresif monyet terhadap pengunjung.

Jika terjadi lebih dari satu kategori tingkah laku agresif dari monyet ekor panjang kepada pengunjung secara berurutan, maka tingkah laku agresif monyet yang dicatat adalah yang levelnya paling tinggi. Pengamatan dilakukan hanya saat cuaca cerah.

Tingkah laku agresif monyet ekor panjang dikelompokkan kedalam 5 kategori merujuk kepada Altmann (1962) dan Cords, (1992), meliputi:

1. Open mouth threat (menyeringai) adalah monyet ekor panjang yang menampakkan giginya dan menaikkan kelopak matanya terhadap pengunjung.

2. Lunging adalah tingkah laku monyet yang bergerak cepat dengan berlari atau melompat kearah pengunjung namun tidak terjadi kontak fisik.

3. Chasing (mengejar) adalah monyet ekor panjang berlari ke arah pengunjung.

4. Body contact (kontak fisik) adalah monyet ekor panjang memegang dan merenggut pengunjung.

5. Biting (menggigit) adalah intensitas agresif yang paling tinggi dimana monyet menggigit pengunjung.

Kategori tingkah laku provokasi dari pengunjung yang menginisiasi terjadinya tingkah laku agresif monyet ekor panjang adalah sebagai berikut (dimodifikasi dari O'Leary dan Fa, 1993):

1. Food exposure (memperlihatkan/ membawa makanan) yaitu pengunjung memperlihatkan atau membawa makanan di dekat monyet ekor panjang.

2. Feeding (memberi makanan) yaitu memberi makan monyet tanpa ada kontak fisik dengan cara meletakkan atau melempar makanan kepada monyet.

3. Contact feeding (memberi makan ditangan) yaitu memberi makanan dengan menggunakan tangan kepada monyet sehingga jari tangan bisa bersentuhan dengan monyet.

4. Threat (mengancam) yaitu pengunjung melakukan tindakan berupa memfoto atau berfoto dengan monyet dari jarak dekat $( \pm 1 \mathrm{~m})$, gerakan lain yang menyebabkan monyet terancam.

5. Direct contact (menyentuh) yaitu meletakkan tangan ketubuh monyet.

6. Close contact (berdekatan) yaitu memposisikan tubuh dekat monyet dalam jarak $\leq 1 \mathrm{~m}$. 
7. Eye contact (kontak mata) menatap tajam ke arah monyet sehingga berhadap-hadapan.

8. Hiting (memukul) yaitu memukul atau menendang monyet dengan tangan atau kaki atau benda lain.

Analisis Data

Agresifitas provokasi dan non-provokasi monyet ekor panjang terhadap pengunjung dikelompokkan menjadi tiga kategori yang dimodifikasi dari Fuentes dan Gamerl, (2005) yaitu:

1. Ringan yaitu open mouth threat.

2. Sedang yaitu lunging dan chasing.

3. Tinggi yaitu body contact dan biting.

Frekuensi aggresif provokasi monyet dibandingkan terhadap bentuk provokasi oleh pengunjung yang dikelompokkan pada tiga situasi yaitu makanan, jarak, dan ancaman. Kemudian, frekuensi setiap jenis agresif provokasi monyet dibandingkan dengan bentuk provokasi pengunjung.

\section{Hasil dan Pembahasan}

\section{Intensitas agresif monyet ekor panjang di Gunung Meru.}

Agresif monyet ekor panjang terhadap pengunjung akibat provokasi lebih tinggi dibandingkan agresif tanpa adanya provokasi (Gambar 1). Kontak fisik merupakan bentuk agresif yang paling sering terjadi akibat provokasi pengunjung. Hal ini seringkali berkaitan dengan usaha monyet dalam mendapatkan makanan dari pengunjung.

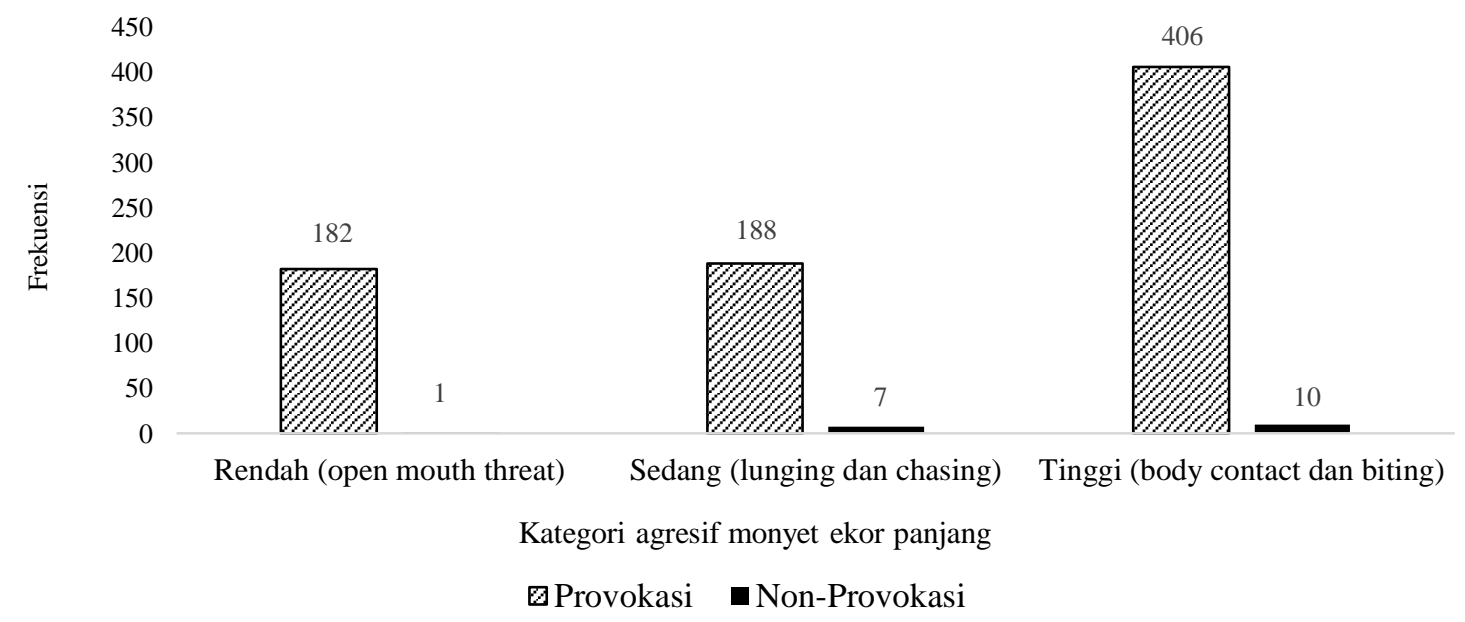

Gambar 1. Perbandingan frekuensi agresifitas provokasi dan non-provokasi monyet ekor panjang terhadap pengunjung di Gunung Meru.

Agresif non-provokasi monyet sangat jarang terjadi yaitu 18 kali dari total 794 kejadian $(0,02 \%)$. Namun kejadian tersebut berlangsung dengan intensitas sedang dan tinggi. Agresif non-provokasi terjadi pada pengunjung yang tidak melakukan interaksi dengan monyet secara langsung, namun dengan keberadaan atau tingkah laku pengunjung bisa saja mengganggu monyet seperti berlari atau melintas dekat monyet. Monyet yang paling sering agresif tanpa provokasi pengunjung adalah monyet jantan dewasa.

\section{Tingkah laku provokasi oleh pengunjung.}

Tingkah laku provokasi pengunjung yang menghasilkan agresif dari monyet ekor panjang terkait dengan 3 faktor utama yaitu makanan (food exposure, feeding, contact feeding), jarak (close contact, direct contact), dan ancaman (threat, eye contact, hiting. 


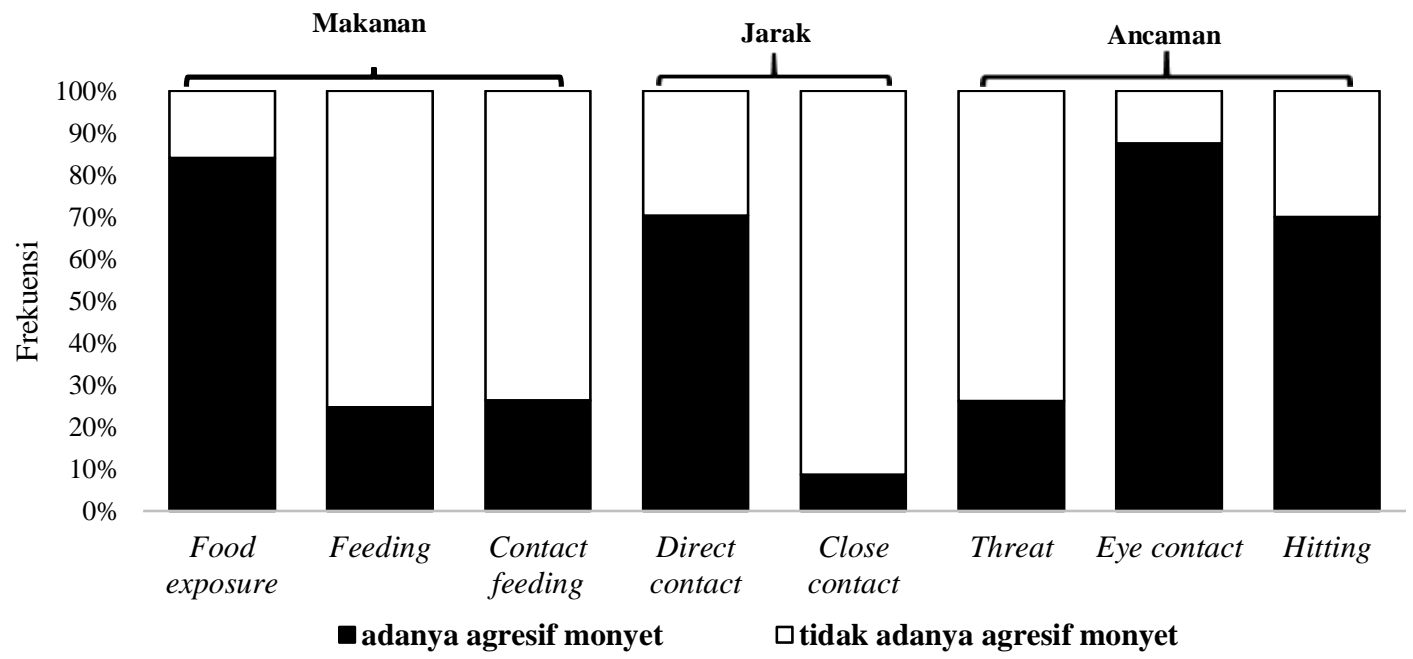

Gambar 2. Jenis provokasi pengunjung dan frekuensi agresi monyet ekor panjang pada tiga situasi (makanan, jarak, dan ancaman dari pengunjung).

Tingkah laku agresif monyet ekor panjang terhadap pengunjung merupakan hasil dari kompetisi terhadap sumber makanan (Gumert, Fuentes, dan Engel, 2011). Interaksi agresif monyet umumnya terjadi ketika pengunjung membawa makanan, dan karena provokasi atau serangan balik dari pengunjung itu sendiri (Sha, 2009). Doenier, Delgiudice, dan Riggs (1997) menyatakan bahwa ketersediaan makanan merupakan faktor penting dalam aktifitas harian hewan. Pengunjung yang memberi makanan terhadap hewan membuat hewan menghabiskan sedikit waktu untuk mencari makan alami, dan memiliki banyak waktu untuk aktifitas lainnya, seperti bersosialisasi, itirahat, dan menjelajah. Saputra, et al. (2014) juga mengatakan monyet ekor panjang terlihat lebih banyak berkumpul dan aktif di tempat yang sering dikunjungi oleh pengunjung, karena mengharapkan untuk mendapatkan makanan dari pengunjung.

Makanan juga penyebab tingginya kontak fisik yang terjadi antara monyet dan pengunjung. Monyet yang menggigit pengunjung beresiko menularkan suatu virus melalui mukosanya. Virus herpes B dan SFV merupakan virus yang ditularkan melalui mukosa (Fuentes dan Gamerl, 2005).

Penelitian serupa yang dilakukan Fuentes dan Gamerl (2005) di Padangtegal,
Bali melaporkan bahwa pemberian makanan oleh pengunjung secara signifikan berkolerasi dengan peningkatan kontak antara pengunjung dengan monyet namun tidak termasuk kasus menggigit, dan kehadiran makanan juga berkolerasi signifikan dengan total frekuensi agresi oleh monyet terhadap pengunjung. Hal ini juga terjadi pada penelitian ini, dimana disaat ketersediaan makanan dari pengunjung lebih banyak, maka kasus kontak fisik yang terjadi antara monyet dan pengunjung juga semakin tinggi. Monyet lebih sering melakukan usaha untuk mendapatkan makanan dari pengunung dengan cara merebut makanan tersebut dari pengunjung.

Berdasarkan hal tersebut, untuk menghindari agresi monyet yang lebih tinggi terhadap pengunjung, maka sebaiknya pemberian makanan terhadap monyet dikurangi. Upaya ini bisa dilakukan oleh pihak pemerintah wisata setempat dengan cara mengeluarkan suatu aturan atau larangan kepada pengunjung terhadap monyet. Seperti yang telah dilakukan di Padangtegal, Bali yaitu adanya papan informasi yang berisi himbauan kepada pengunjung untuk tidak menyentuh atau menggertak monyet, meminta bantuan kepada pemandu dalam pemberian makanan kepada monyet, atau dilarang menyembunyikan makanan didepan monyet (Fuentes, 2006). 
Jurnal Biologi Universitas Andalas (J. Bio. UA.)

4(4) - Desember 2015: 258-263 (ISSN : 2303-2162)

Tingkah laku pengunjung yang berkaitan dengan bentuk ancaman (threat) lebih beresiko tinggi menimbulkan tingkah laku agresif monyet ekor panjang. Menatap tajam kearah monyet merupakan bentuk provokasi pengunjung yang paling sering menimbulkan agresif. Berfoto dengan monyet juga menjadi penyebab timbulnya agresif monyet. Namun biasanya bentuk provokasi seperti ini terjadi setelah pengunjung melakukan provisioning terhadap monyet.
Provokasi pengunjung yang berkaitan dengan makanan (food exposure, feeding, contact feeding) menghasilkan agresif monyet yang lebih sering dalam bentuk kontak fisik (seperti memegang tubuh pengunjung, merebut makanan dari tangan pengunjung, dan memanjat tubuh pengunjung). Sedangkan provokasi yang terkait jarak (direct contact) dan ancaman (threat, eye contact dan hiting) menghasilkan agresif monyet yang lebih sering dalam bentuk open mouth threat (Gambar 3).

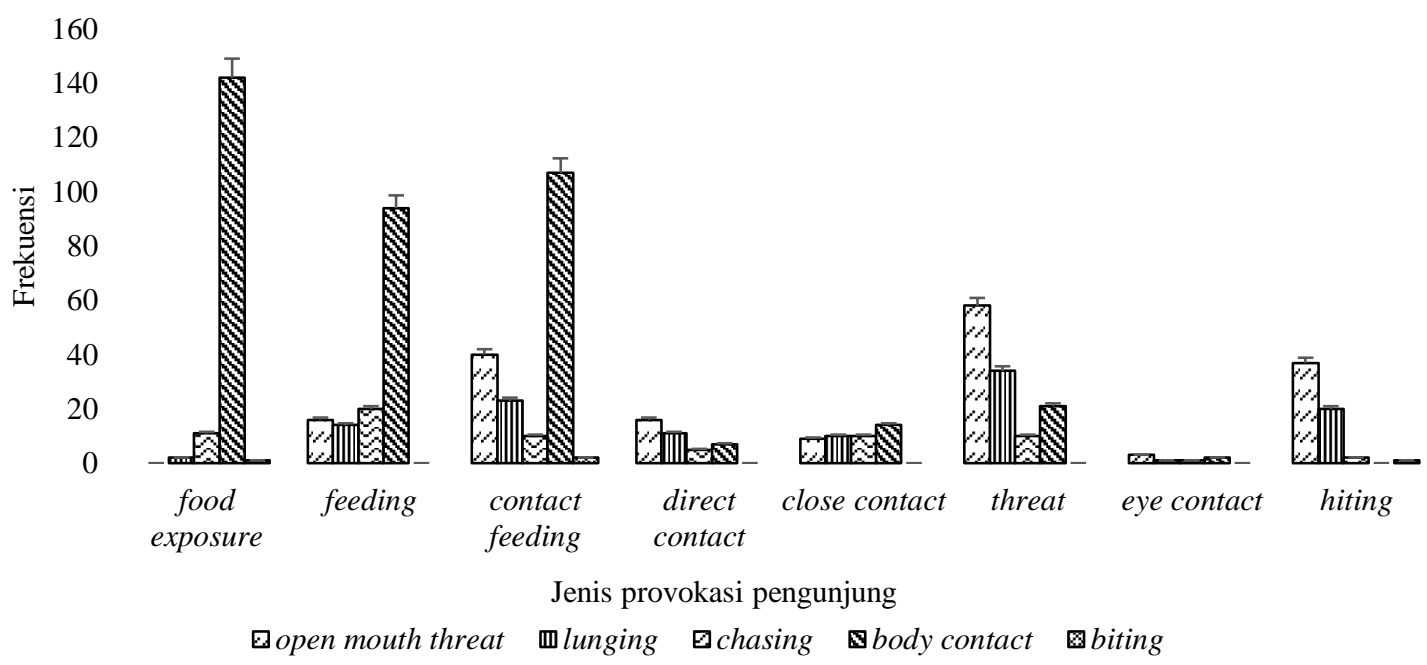

Gambar 3. Frekuensi agresif monyet ekor panjang akibat diprovokasi pengunjung

Direct contact dan close contact merupakan bentuk provokasi lanjutan dari provokasi pengunjung yang terkait dengan makanan. Pengunjung yang memberi makanan kepada monyet, selanjutnya akan mendekati dan menyentuh monyet untuk keperluan hiburan (seperti memfoto atau berfoto dengan monyet) atau kepuasan tersendiri karena telah berhasil menaklukkan monyet (Ilham, et al., 2016). Hal ini juga diungkap oleh Orams (2002), bahwa berdekatan dengan binatang merupakan hal yang sangat berarti bagi pengunjung dimana pengunjung akan merasa dekat dengan alam.

\section{Kesimpulan}

Berdasarkan hasil yang telah didapatkan, bisa disimpulkan bahwa intensitas agresif monyet terhadap pengunjung lebih banyak terjadi akibat provokasi dari pengunjung dibandingkan non-provokasi dari pengunjung. Kategori agresifitas provokasi dan non-provokasi monyet ekor panjang di Gunung Meru termasuk kedalam kategori tinggi (kontak fisik dan menggigit). Provokasi pengunjung terkait makanan menjadi penyebat seringnya terjadi agresif monyet dalam bentuk kontak fisik.

\section{Ucapan Terima Kasih}

Terima kasih kepada Ruhama Maya Sari dan Afdhal Tisyan yang telah membantu dalam pengambilan data, dan Ibu Mawar yang telah memberikan akomodasi selama penelitian.

\section{Daftar Pustaka}

Altmann, S. A. 1962. A Field Study of The Sociobiology of Rhesus Monkey, Macaca mulatta. Annals New York 
Jurnal Biologi Universitas Andalas (J. Bio. UA.)

4(4) - Desember 2015: 258-263 (ISSN : 2303-2162)

Academy of Sciences, Vol. 102: 338435.

Altmann, J. 1974. Observational Study of Behavior: Sampling Methods. Alle Laboratory of Animal Behavior. University of Chicago. Chicago, Illinois, USA.

Beisner, B. A., Heagerty, A., Seil, S. K. Balasubramaniam, K. N., Atwill, E. R., Gupta, B. K., Tyagi, P. C., Chauhan, N. P. S., Bonal, B. S., Sinha, P. R., dan McCowan. 2014. HumanWildlife Conflict: Proximate Predictors of Aggression between Humans and Rhesus Macaques in India. American Journal of Physical Anthropology 00:01-09.

Cords, M. 1992. Post-Conflict Reunions and Reconciliation in Long-Tailed Macaque. Animal Behaviour, 44: 5761.

Doenier, P. B., Delgiudice, G. D., dan Riggs, M. R. 1997) Effects of Winter Supplemental Feeding on Browse Consumption by Whitetailed Deer. Wildlife Society Bulletin, 25, 235-243.

Fa, J. E. 1992. Visitor-Directed Aggression among the Gibraltar Macaques. Zoo Biology 11:43-52.

Fuentes, A. and S. Gamerl. 2005. Disproportionate Participation by Age/Sex Classes in Aggressive Interactions Between Long-Tailed Macaques (Macaca fascicularis) and Human Tourists at Padangtegal Monkey Forest, Bali, Indonesia. American Journal of Primatology 66: 197-204.

Fuentes, A. 2006. Human Cultural and Monkey Behavior: Assessing the Contexts of Potential Pathogen Transmission between Macaque and Humans. American Journal of Primatology 68:880-896.

Gumert, M. D., A. Fuentes, L. J. Engel. 2011. Monkeys on the Edge Ecology and Management of Long-Tailed Macaques and Their Interface with Humans. United States of America by

Cambridge University Press. New York.

Ilham, K. 2013. Pengaruh Peringkat Jantan Dewasa terhadap Aktivitas Grooming. Skripsi Sarjana Biologi. FMIPA Universitas Andalas.

Ilham, K., Rizaldi, Nurdin, J., Tsuji, Y. 2016. Status of Urban Populations of The Long-Tailed Macaque (Macaca fascicularis) in West Sumatra, Indonesia. Primates.

Koyama, N. 1984. Socio-Ecologycal Study of the Crab-Eating Monkeys at Gunung Meru, Indonesia. Kyoto University Overseas Research Report of Studies on Asian Non-Human Primates, 3: 17-36.

Martin, P., dan P. Bateson. 1993. Measuring Behaviour an Introductory Guide Second Edition. The Press Syndicate of the University of Cambridge. The Pitt Building, Trumpington Street, Cambridge, United Kingdom.

O'Leary H., dan J. E. Fa. 1993. Effects of Tourists on Barbary Macaque at Giblartar. Folia Primatol 61: 77-91.

Orams, M. B. 2002. Feeding wildlife as a tourism attraction: a review of issues and impacts. Tourism Management, 23: 281-293.

Saputra, K.G. W., N. L.Watiniasih, I. K. Ginantra. 2014. Aktivitas Harian Kera Ekor Panjang (Macaca Fascicularis) di Taman Wisata Alam Sangeh, Kabupaten Badung, Bali. Jurnal Biologi XVIII (1): 14-18. ISSN: 14105292.

Schilaci, M. A., et al., 2010. The Not-SoScared Monkeys of Bali: A Radiographic Study of human Primate Commensalism. Indonesian Primates. Developments in Primatology: Progress and Prospects, pp 249-256.

Sha, J. C. M., Gumert, M. D., Lee, B. P. YH., Engel, L. J., Chan, S., Fuentes, A. 2009. Macaque-Human Interactions and the Societal Perceptions of Macaques in Singapore. American Journal of Primatology, 71: 825-839. 
Jurnal Biologi Universitas Andalas (J. Bio. UA.)

4(4) - Desember 2015: 258-263 (ISSN : 2303-2162) 